\begin{tabular}{ll}
\hline \hline MINING AND METALLURGY INSTITUTE BOR & ISSN: 2334-8836 (Štampano izdanje) \\
UDK: 622 & ISSN: 2406-1395 (Online) \\
\hline \hline
\end{tabular}

\title{
COMPARATIVE ANALYSIS OF INFLOWS AND SECTORAL DISTRIBUTION OF THE FOREIGN DIRECT INVESTMENTS FLOWS
}

\begin{abstract}
Foreign direct investment is directly dependent on the economic and, therefore, the overall social progress in the world. The decrease or increase of foreign direct investment global flows result in a fall or increase in economic indicators that measure and reflect the economic trends and results of the global economy. Being one of the most important elements, if not the most important, in strengthening the world economy, the foreign direct investment plays a very important role in achievement the sustainable development goals that require investments into the basic infrastructure, energy, water supply, climate change alleviation, education, healthcare, as well as the production capacities in order to generate the new jobs and higher incomes. The aim of this study is to emphasise the significance of foreign direct investment flows, as well as to conduct a comparative analysis of sectoral distribution of these flows, since, depending on the sector, the foreign direct investments have different effects on the economic development of the host country.
\end{abstract}

Keywords: foreign direct investments, economic indicators, world economy, sustainable development, sectoral distribution

\section{INTRODUCTION}

Individuals and groups of people exchanged the goods and services across borders of their countries, invested in the mines and factories in other countries for centuries. An indicator that reveals how fast is the international business expansion, is a foreign direct investment (FDI). [10] FDI, as a form of international capital movement, has been dated since the ancient times. Until the beginning of the $20^{\text {th }}$ century, it was difficult to assess the world stock and total FDI flows based on the data about total foreign investments, since they consist of the direct and portfolio investments. [5]

[5] As time passed by, the FDIs have become an increasingly important form of international business and international capital flows for all countries. For developed countries, the FDIs represent a form of international capital flows of growing importance, and for developing countries and countries in transition, the most significant form of international capital movements. [11] The end of the $20^{\text {th }}$ and the beginning of the $21^{\text {st }}$ century represent a period of intensive growth of the international orientation and international activities of companies, and consequently, a growth of the international business and international investment.

Compared to the other two forms of international capital flows (loan capital and portfolio investment), the FDIs are highly represented in financing the global world economy and national economies of individual countries. The growth of global FDI flows is conditioned by:

\footnotetext{
*High Economic School Vocational Studies Pec in Leposavic e-mail:bobandasickg@gmail.com,savic22@yahoo.com
} 
a) liberalization and deregulation of the international capital market,

b) codification of the foreign capital protection system (the so-called national treatment), which has recently encouraged the reinvestment of profits,

c) the growing technological gap between the certain categories of countries (high and unachievable financial threshold for entry into areas of the new technologies);

d) the new approaches in development and economic policies (the concept of an open economy with a flexible exchange rate), based on a new ownership (privatization in Central and Eastern European countries) and foreign trade (free customs zones in PR China) regimes, creating a stimulating ambient for the foreign capital inflows,

e) the successful stabilization and macroeconomic policies of a number of significant developing countries (Brazil, Mexico, ...) with a high external debt service coefficient and

f) the emergence of the new countries with excess capital and need to create the new markets (the countries of Southeast Asia, the so-called "Little Tigers"). [9]

Among the many effects that the FDI produces, their development potential is certainly the most important, since by unifying trade, the capital and technology flows into a whole under unified control and governance, they significantly influence the establishment of international relations, as well as the overall efficiency of functioning the world economy. Under the modern business circumstances, in the new global world and under the conditions of the new economic order, the FDIs play a role of an important lever of economic growth and development.

Funding through the FDI can be realized through the Greenfield or Brownfield in- vestments, joint ventures and international Merchants and Acquisitions ( $M$ \& A). Please note that after several years of business, it is not possible to differentiate the FDI by the way of entry, although at the moment of entering the country and in the short term period, the host country in some aspects has more benefits from the Greenfield than the other types of FDI. [2]

\section{GLOBAL FDI FLOWS}

Since 1991, the United Nations Conference on Trade and Development (UNCTAD) has been issuing the World Investment Report (WIR) once a year. The Figure 1 shows that in 2007 the total FDI inflow was 1,978 billion. USD, the year with the highest inflow of FDI in the history of mankind. [13] The global financial crisis in 2008 led to a collapse of international capital flows, as the investors became more cautious and banks were reluctant to borrow the capital internationally. In addition to the global economic crisis, recession and turmoil in financial markets in the world have had a negative impact on global FDI flows. Thus, over the past three decades, one of the most significant characteristics of the global economy is the shift in the period of rise and fall of the total international capital flows in the world. Only in 2015 (USD 1,921 billion) the approximate inflow of FDI flows was the same as it was in 2007 (the year with the highest inflow of FDI in the history of mankind). After that, in 2016, there was a slight decline in the world investment flows (USD 1,867 billion).

According to the latest World Investment Report 2018, the FDI flows globally dropped to 1.429 billion USD in 2017 , which is a $23 \%$ decrease compared to 2016. Developed economies (37\%) and transitional economies $(27 \%)$ did worse than the global average, while developing economies kept the FDI volume at the 2016 level, leaving them the most valuable and most 
regular external source of financing for these economies (see Figure 1). Developed economies still have dominant participation in the world investment flows. The connection of FDI flows and economic activity in developed economies is obvious. Looking at 2017, out of the total FDI inflows in the world, 712 billion USD or almost $50 \%$ goes to the developed economies; 670 billion
USD or over $46 \%$, goes to the developing economies, whereas 64 billion USD or less than $5 \%$ of the total FDI inflow in the world (see Table 1) goes to the economies in transition. The FDI remained the most valuable and most regular external source of financing for these economies, compared to the portfolio investments, remittances and official development aid programs. [4]

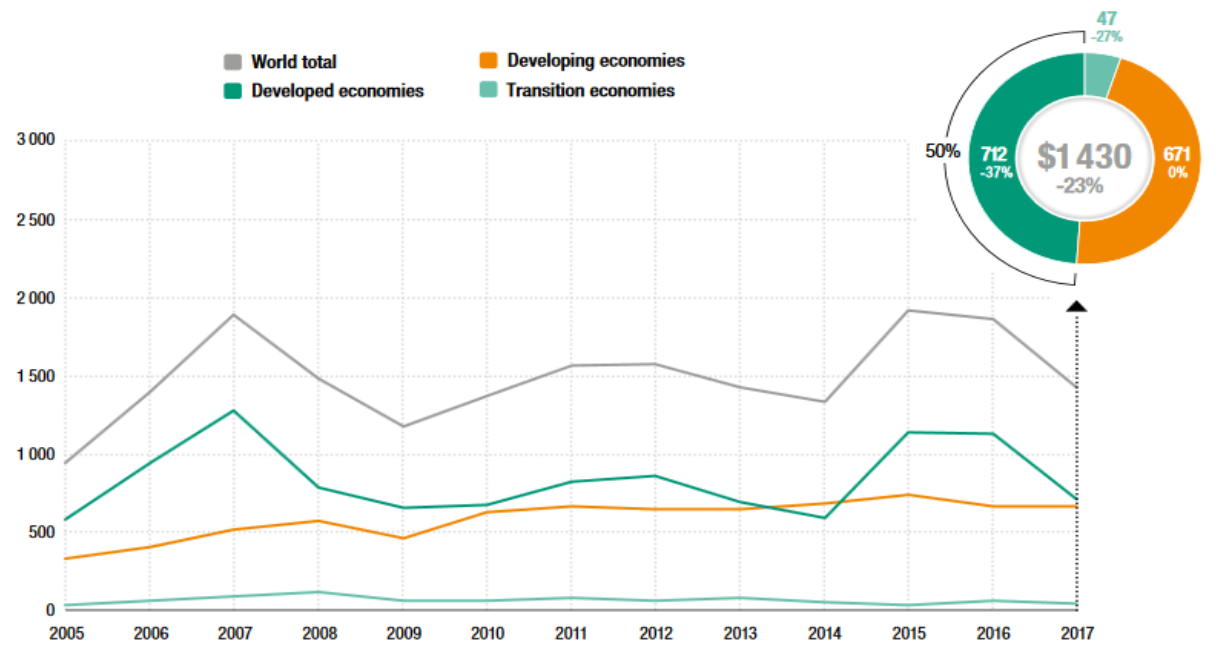

Figure 1 Flows of the FDI inflows in the world and by groups of countries, 2012-2017 (in billion USD and \%) [14, p. 184-187]

Table 1 Flows of the FDI inflows in the world and per groups of countries, 2012-2017 (in billion USD) [14, p. 184-187]

\begin{tabular}{|l|c|c|c|c|c|c|}
\hline Economy/year & 2012 & 2013 & 2014 & 2015 & 2016 & 2017 \\
\hline Developed economies & 858 & 693 & 596 & 1,141 & 1,133 & 712 \\
\hline Developing economies & 651 & 648 & 685 & 744 & 670 & 670 \\
\hline Transitional economies & 64 & 83 & 56 & 36 & 64 & 47 \\
\hline World total & 1,574 & 1,425 & 1,338 & 1,921 & 1,867 & 1,429 \\
\hline
\end{tabular}

A decline in the FDI inflows compared to 2016 is particularly high in the countries of the European Union (42\%), North America $(39 \%)$, in other developed non-EU countries (26\%) and Africa (21\%). The Asian countries kept the FDI inflow at the 2016 level. The FDI inflow growth has a group of countries in the "Other Developed Economies" (7\%) and Latin America and the Caribbean (8\%) (see Figure 2).

The decrease of the FDI flows in 2017 was resulted by decrease in the net value of M \& As, from 887 billion USD to 694 billion USD in 2016 (decline of 22\%). 
Moreover, decline of the Greenfield investments value was noted by $14 \%$ ( $\$ 833$ billion in 2016 versus $\$ 720$ billion in 2017).

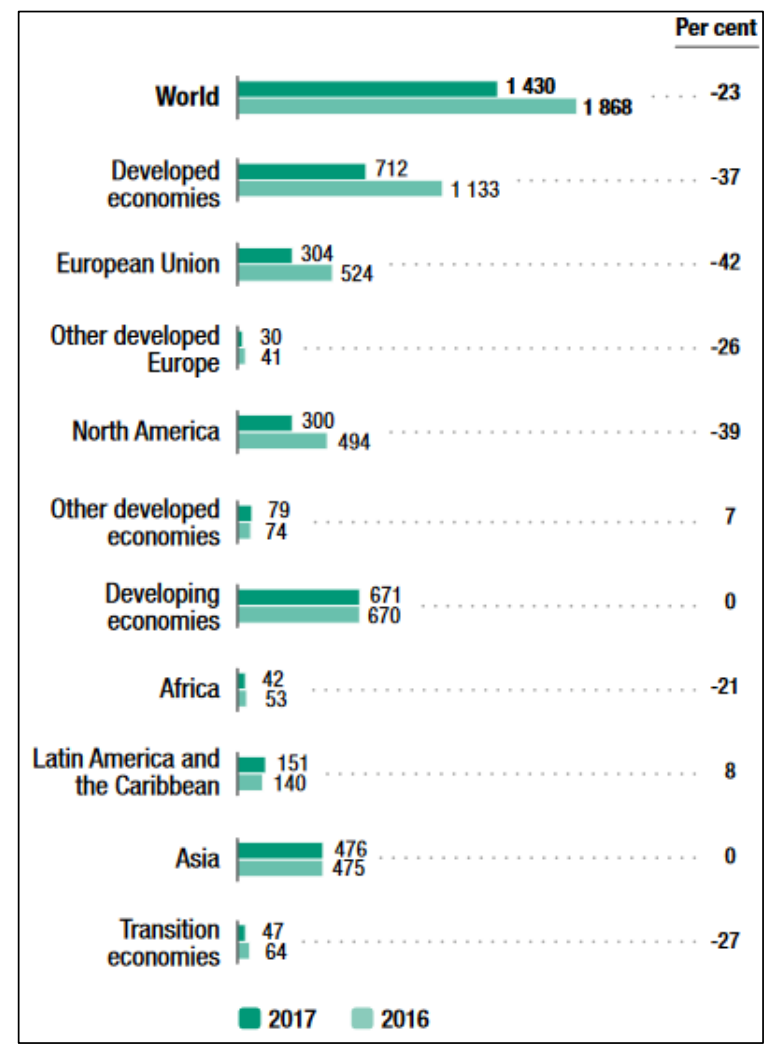

Figure 2 Inflow of the FDIs, worldwide and per regions, 2016-2017 (in billion USD and \%) [14, p. 3]

Most FDIs in the world were received by the USA ( 275 billion USD). In the leading 20 host/countries of the FDI from a group of developed economies the US is followed by the Netherlands (USD 58 billion), France (USD 50 billion), Australia (USD 46 billion), Switzerland (USD 41 billion), Germany 35 billion USD), Ireland (USD 29 billion), Canada (USD 24 billion), Spain (USD 19 billion), Israel (USD 19 billion) and Italy (17 billion USD).

Of the developing economies, China has the highest FDI inflow in the amount of 136 billion USD (thus being the second in the world, right behind the US). It is followed by Hong Kong (USD 136 billion), Brazil (USD 63 billion), Singapore (USD 62 billion), India (USD 40 billion), Mexico (USD 30 billion), Indonesia (USD 23 billion)) and the Republic of Korea (USD 17 billion).

Regarding to the transition economies, Russia (USD 25 billion) is ranked the $14^{\text {th }}$ of the 20 leading host countries. Half of the top 10 host countries belong to the developing economies (see Figure 3).

These 20 leading host countries account for around $80 \%$ of the global FDI inflows, while the all other countries account for just over $20 \%$. 
Political uncertainty over the global trade, not only with Brexit, but also with the US pulling out of the Trans-Pacific Partnership (TPP), renegotiating the North American Free Trade Agreement (Oil), and taking a generally aggressive view on global trade, has also created significant uncertainty for location decisions - especially in the export-oriented industries that are dependent on the free-market access. The other big factor in the decline of FDI in 2017 was the Chinese FDI policy, with the reimposition of controls on overseas FDI which curtailed the FDI in certain targeted sectors. [6]

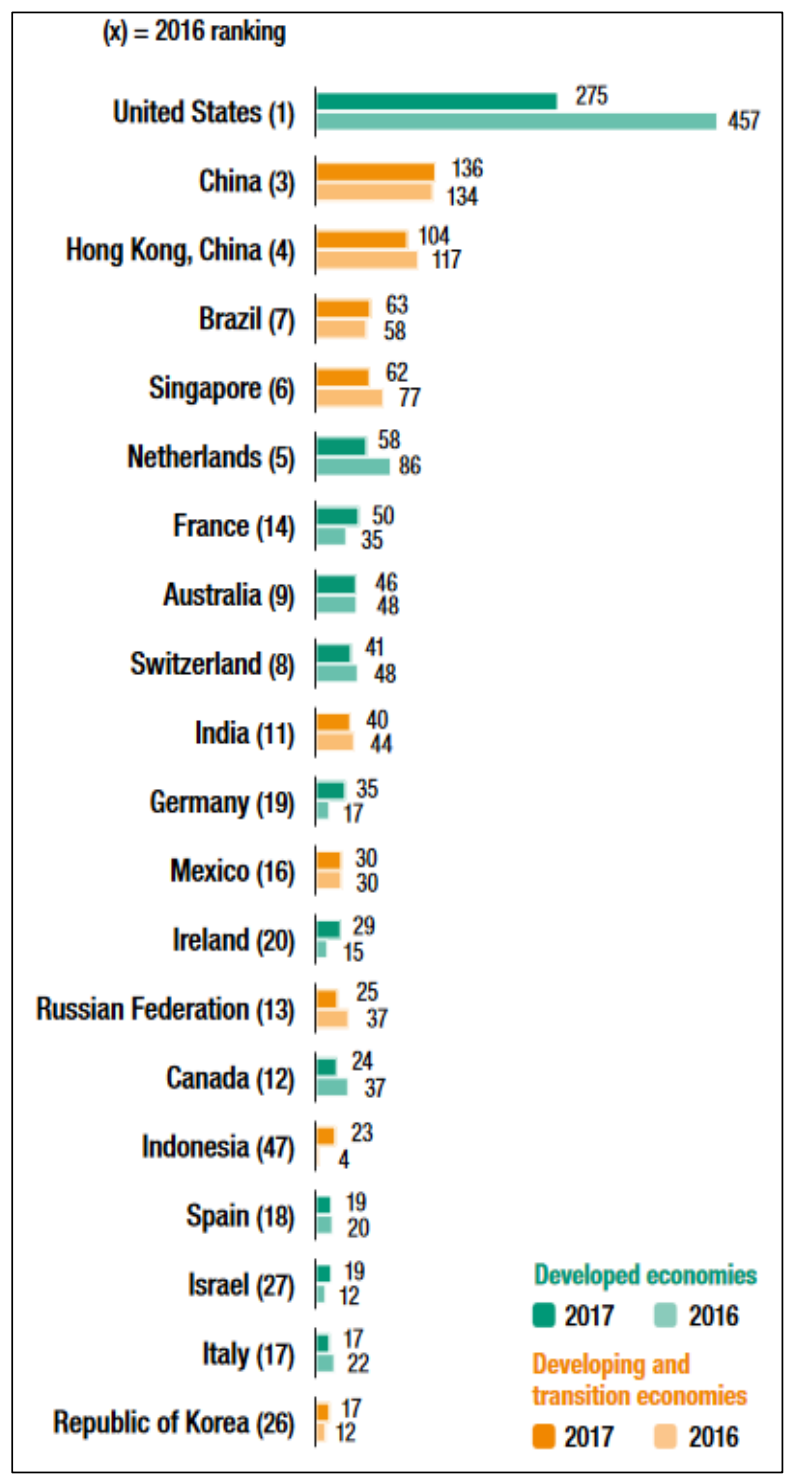

Figure 3 Inflow of the FDIs, per regions, 2016-2017 (in billion USD and \%) [14, p. 3] 


\section{FDI DISTRIBUTION PER SECTORS}

The sectoral distribution of the FDI flows worldwide has changed over the years. In the beginning of the $20^{\text {th }}$ century (1914), 55\% of the FDIs recorded at the global level went to the exploitation of natural resources, while the ratio of services and industrial production was $30 \%$ : 15\%. [7] Based on this data, it can be concluded that during that period the FDIs were largely focused on the primary sector (provision of raw materials and production materials) and the economic infrastructure related to this production. [3]

A rapid decline in the FDI in exploitation the natural resources was observed in the eighties of the twentieth century, while it was increased in the secondary sector (industrial production) and service activities.

The last decade of the XX and the first decade of the $21^{\text {st }}$ century are characterized

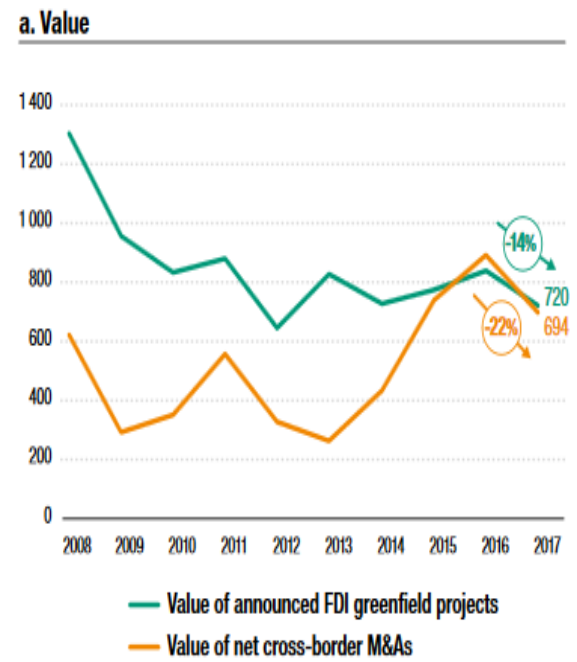

by the reorientation of the FDI flows towards the service sector. The FDIs grew in all three sectors, primary, secondary and tertiary, but the largest, growing part went to the tertiary sector. In the period 19902009 , a share of services in the total stock of FDIs input in the world increased from $49 \%$ to $63 \%$, while a share of the other two sectors dropped significantly: the primary from $9.4 \%$ to even lower $7.3 \%$, and especially the secondary from $41 \%$ to $27.6 \%$. [12]

Nowadays, we are at the daybreak of the fourth industrial revolution. We are witnesses of advancement the new technologies and robotics that make production faster, cheaper and better than ever before, creating huge opportunities for economic growth and sustainable development, so it is to be expected that the FDI flows will mostly go to these types of sectors.

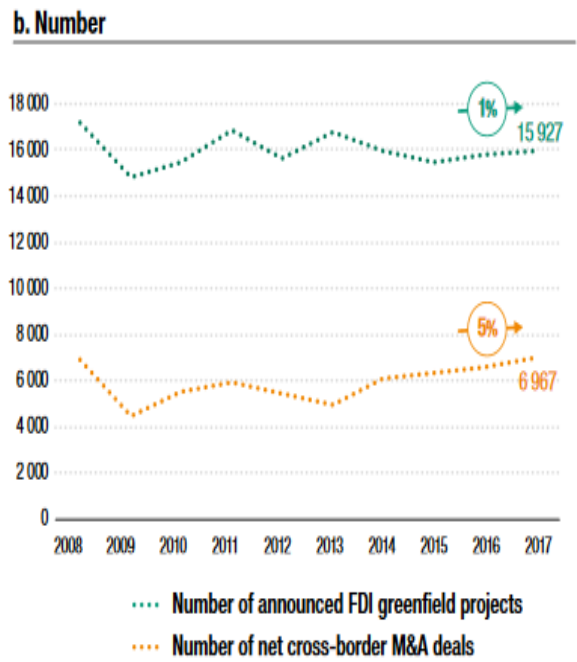

Figure 4 Value and number of net cross-border $M \& A s$ and announced SDI Greenfield projects, 2008-2017 (billion USD and number) [14, p. 7]

As noted, in 2017 there was a decrease in the value of M\&A, as well as the values of Greenfield foreign investments in com- parison to 2016. On the other hand, there was an increase in the number of $\mathrm{M} \& \mathrm{~A}$ operations by $1 \%(6,607$ in 2016 versus 
6,967 in 2017) and announced Greenfield foreign projects by $5 \%(15,766$ in 2016 versus 15,927 in 2017). Observing the period 2008-2017, there were periods of decline and growth in both the value and number of net cross-border M\&A and the Greenfield foreign projects (see Figure 4 under $\mathrm{a}$ and $\mathrm{b}$ ).

Table 2 Value and number of net cross-border $M \& A$, per sectors and selected industries, 2016-2017 [14, p. 8]

\begin{tabular}{|l|c|c|c|c|c|c|}
\hline \multirow{2}{*}{ Total } & \multicolumn{3}{|c|}{ Value (billion of dollars) } & \multicolumn{3}{|c|}{ Number } \\
\cline { 2 - 7 } & 2016 & 2017 & $\%$ & 2016 & 2017 & $\%$ \\
\hline Primary & $\mathbf{8 8 7}$ & $\mathbf{6 9 4}$ & $\mathbf{- 2 2}$ & $\mathbf{6 6 0 7}$ & $\mathbf{6 9 6 7}$ & $\mathbf{5}$ \\
\hline Manufacturing & 83 & 24 & -70 & 206 & 550 & 167 \\
\hline Services & 406 & 327 & -19 & 1745 & 1690 & -3 \\
\hline
\end{tabular}

Top 10 industries in value terms:

\begin{tabular}{|l|c|c|c|c|c|c|}
\hline Chemicals and chemical products & 130 & 137 & 5 & 345 & 322 & -7 \\
\hline Business services & 75 & 107 & 43 & 1716 & 1817 & 6 \\
\hline Food, beverages and tobacco & 138 & 88 & -36 & 200 & 227 & 14 \\
\hline Finance & 97 & 59 & -39 & 585 & 617 & 5 \\
\hline Electricity, gas and water & 66 & 54 & -18 & 209 & 171 & -18 \\
\hline Machinery and equipment & 32 & 52 & 63 & 195 & 183 & -6 \\
\hline Information and communication & 24 & 39 & 66 & 618 & 611 & -1 \\
\hline Electrical and electronic equipment & 75 & 26 & -66 & 349 & 307 & -12 \\
\hline Transportation and storage & 46 & 23 & -51 & 293 & 306 & 4 \\
\hline Mining, quarrying and petroleum & 79 & 23 & -71 & 138 & 466 & 238 \\
\hline
\end{tabular}

A decline in the value of net crossborder M\&A, for the period 2016-2017, was reduced in all three sectors (see Table 2). The largest decline was recorded in the primary sector $(-70 \%)$, production $(-19 \%)$ and services $(-14 \%)$. The number of M\&A deals in extractive industries (mining, quarrying and petroleum) got almost tripled, however the value of these transactions was lower by $71 \%$ compared to 2016.

At the level of the industry, in addition to the extractive industry, there was also a decline in the industry of electrical and electronic equipment $(-66 \%)$ and the food, beverage and tobacco industry $(-36 \%)$. On the other hand, there was the growth of M\&A's value in the information and communication industry (66\%), machinery and equipment industry (63\%), business services (43\%) and the chemicals and chemical industries $(5 \%)$. Only M \& A business services had a positive result both in terms of value (43\%) and number of projects (6).

By observing the value of announced Greenfield FDI projects, there was a drop of value in the primary sector $(-61 \%)$ and services $(-25 \%)$, while production was growing $(14 \%)$. The value of Greenfield projects in production and services is approximately the same and amounts was about 350 billion USD in 2017, thus these two sectors participated with more than $97 \%$ in the Greenfield 
FDI projects (less than $3 \%$ goes to the primary sector). The Greenfield FDI projects value drop was recorded in construction $(-51 \%)$, public utilities - electricity, gas and water $(-26 \%)$, transportation, storage and communication $(-26 \%)$ and business services $(-16 \%)$.

Table 3 Value and number of announced FDI Greenfield projects per sectors and selected industries, 2016-2017 [14 p. 8]

\begin{tabular}{|l|c|c|c|c|c|c|c|}
\hline \multirow{2}{*}{ Total } & \multicolumn{3}{|c|}{ Value (billions of dollars) } & \multicolumn{3}{c|}{ Number } \\
\cline { 2 - 7 } & 2016 & 2017 & $\%$ & 2016 & 2017 & $\%$ \\
\hline Primary & $\mathbf{8 3 3}$ & $\mathbf{7 2 0}$ & $\mathbf{- 1 4}$ & $\mathbf{1 5 7 6 6}$ & $\mathbf{1 5 9 2 7}$ & $\mathbf{1}$ \\
\hline Manufacturing & 54 & 21 & -61 & 52 & 63 & 21 \\
\hline Services & 295 & 338 & 14 & 7703 & 7678 & 0 \\
\hline Top 10 industries in value terms: & 484 & 362 & -25 & 8011 & 8186 & 2 \\
\hline Electricity, gas and water & 129 & 95 & -26 & 404 & 296 & -27 \\
\hline Business services & 96 & 80 & -16 & 4125 & 4278 & 4 \\
\hline $\begin{array}{l}\text { Motor vehicles and other } \\
\text { transport equipment }\end{array}$ & 56 & 62 & 12 & 1077 & 1103 & 2 \\
\hline Construction & 126 & 62 & -51 & 322 & 276 & -14 \\
\hline $\begin{array}{l}\text { Chemicals and chemical } \\
\text { products }\end{array}$ & 43 & 61 & 42 & 804 & 856 & 6 \\
\hline $\begin{array}{l}\text { Electrical and electronic } \\
\text { equipment }\end{array}$ & 44 & 52 & 20 & 1005 & 958 & -5 \\
\hline $\begin{array}{l}\text { Transport, storage and } \\
\text { communications }\end{array}$ & 56 & 41 & -26 & 935 & 903 & -3 \\
\hline Trade & 27 & 32 & 21 & 902 & 1001 & 11 \\
\hline Food, beverages and tobacco & 24 & 29 & 17 & 596 & 664 & 11 \\
\hline Textiles, clothing and leather & 28 & 28 & 1 & 1558 & 1476 & -5 \\
\hline
\end{tabular}

The number of Greenfield FDI projects is similar to 2016 , with a the growth of $21 \%$ in the primary sector, and drop of value for $14 \%$. With regards to the number of Greenfield FDI projects per industry, the utility services - electricity, water and gas $(-27 \%)$, construction $(-14 \%)$, electrical and electronic equipment $(-5 \%)$ and transport, storage and communication $(-3 \%)$ recorded drops, while the growth of the number of FDI Greenfield projects is recorded by other sectors (see Table 3 ).

The sectoral distribution of the FDIs has largely depended on the strategic and economic motives of investors. [8]
According to the sectoral analysis done by FDI Intelligence (it only monitors Greenfield investment projects, that is, it does not include $M$ \& $A$, intercompany loans, equity investments, or other forms of cross-border investment, but exclusively those that involve starting business from the very beginning without the previous infrastructure, business premises and workers) key trends in 2017 include:

- Coal, oil and natural gas reclaimed the top spot for capital investment in 2017 with $\$ 79.6$ billion of FDI recorded.

- The top three sectors by number of projects in 2017 were software and IT 
services, business services, and financial services, with financial services replacing the third-ranked sector of 2016, industrial machinery, equipment and tools.

- Software and IT services again maintained its place as the top sector for project numbers, with 2237 in 2017, up $5 \%$ from 2016.

- Of the top five sectors by number of projects, software and IT services and financial services were the only two to achieve growth.

- Communications witnessed a $14 \%$ decrease, by the number of projects after showing an increase in 2016.

- Real estate saw an increase of $16 \%$ in project numbers in 2017, though the capital investment dropped by $49 \%$ to $\$ 79.5$ billion.

- Chemicals saw a 58\% increase in capital investment in 2017, with a slight drop in the project numbers of $2 \%$.

- The biggest decline in the project numbers comprised the sectors of communications (-14\%), automotive components $(-14 \%)$ and business services $(-7 \%)$. [6]

Sectoral composition of the FDI flows plays an important role and impact on the economic growth. [1]

A trend of sectoral distribution of the FDI shows different patterns. In developed economies, foreign investments in the tertiary sector and the service sector are the most represented. Developing and underdeveloped economies have a relatively high share of investment into the primary and secondary sectors, although the service sector shows significant growth.

\section{CONCLUSION}

The FDI, whose bearers are transnational company (the main leverage through which the international transfer of capital is carried out), represent the dominant form of international capital movement, recording expansive growth, affirming and increasing the role of international production in the world economy. The role of FDI as a very important form of financing the global economy has been particularly strong in the last two decades of the twentieth century, while in the beginning of the $21^{\text {st }}$ century they were a predominant form of financing, especially in developing economies and economies in transition. Such a trend will continue in the years to come. Developed economies are predominant in the global FDI flows, followed by developing economies and at the end of the economies in transition. When it comes to the sectoral distribution, the service sector is represented by more than $50 \%$ of the total value of the realized FDI.

Development of the country is in direct correlation with the sectoral distribution of FDIs. Developed economies attract the most foreign investments in the tertiary sector, while investments in the primary and secondary sectors are prevalent in develo-ping and transition economies. Investments into the primary sector, i.e. the production and exploitation of the natural resources, oil and gas, are likely to continue in the same scale, if not even more, because of a high demand for energy in the world.

\section{REFERENCES}

[1] Aukut D.; Sayek S.: The Role of the Sectoral Composition of Foreign Direct Investment on Growth, in: Do Multinationals Feed Local Development and Growth? International Business and management, Volume 22, Edited by: Piscitello L.; Santangelo D. G., Elsevier, Amsterdam, 2007, p. 49. (35-62).

[2] Begović B.; Mijatović B.; Paunović M.; Popović D.: Greenfield Foreign Direct Investment in Serbia, Center for Liberal Democratic Studies, Belgrade, 2008, p. 15 (in Serbian) 
[3] Dašić B.: Foreign Direct Investments and Regional Development of Serbia, Monography, Higher Economic School of Professional Studies Pec in Leposavic, Neven, Zemun, 2011, p. 55 (in Serbian)

[4] Dugalić V.: Foreign Direct Investments - Trends and Expectations, Banking, Association of Bank of Serbia, Belgrade, vol. 46, no. 3, 2017, p. 6(6-13)

[5] Dunning J. H.: Multinational Enterprises and the Global Economy, Addison-Wesley Publishing Company Inc., Wokingham, Berkshire, England, 1993, p. 117, 118.

[6] FDI Inteligence: The FDI Report 2018 Global Greenfield Investment Trends, Financial Times, 2018, p. 2.

http://minisites.specialist.titles.s3website-eu-west-1.amazonaws.com/ fdiintelligence.com/report/2018/thanky ou.html (Date of access: 15/01/2018)

[7] Jones G.: The Evolution of International Business: An Introduction, Routledge, London and New York, 1996, p. 32.

[8] Nestorović O.: Foreign Direct Investments as a Factor of Sustainable Development of the Serbian Economy, Doctoral Dissertation, Faculty of Economics, Kragujevac, 2015, p. 19 (in Serbian)
[9] Popović T.: Current Developments in the International Environment and Yugoslavia - the Model of Transition and Transition Potential of Yugoslavia, Compilation of Works - the $21^{\text {st }}$ Century Development Challenges, Institute of Economic Sciences, Belgrade, 1999, p. 4 (in Serbian)

[10] Radević B.; Stojadinović Jovanović S.; Dašić B.: International Business and Finance, Department of Economic Sciences, State University in Novi Pazar, Grafikolor, Kraljevo, 2016, p. 28.

[11] Stojadinović Jovanović S.: Contemporary Trends in Global Flows of Foreign Direct Investments, International Problems, No. 1/2015, Institute for International Politics and Economy, Belgrade, 2015, p. 83 (in Serbian)

[12] Stojadinović Jovanović S.: Foreign Direct Investments as a Form of Financing the Global Economy, Banking, 1/2013, Association of Serbian Banks, Belgrade, p. 40-42 (34-57) (in Serbian)

[13] UNCTAD: World Investment Report 2009, New York and Geneva, 2009, p. 247.

[14] UNCTAD: World Investment Report 2018, New York and Geneva, 2018, p. 184-187. 